Ind. Health, 1964, 2, 199.

\title{
ON THE CHARACTERISTICS OF THE DIGITAL DUST INDICATOR
}

\author{
Shigezi KOSHI \\ National Institute of Industrial Health, Kizuki-Sumiyoshi, Kawasaki
}

(Received September 10, 1964)

Characteristics of the Digital Dust Indicator were examined, and the following equation was derived to express the response $R$ of it,

$$
\mathbf{R}=\mathbf{K} \sigma \frac{\mathbf{C}}{\mathbf{p}} \exp \cdot\left(-\theta \frac{\mathbf{C}}{\mathbf{p}}\right)
$$

where $K$ is the constant, $\sigma$ is the relative scattering coefficient of dust, $p$ is the dissipation coefficient of dust particles, $\theta$ is the linear function of the extinction coefficient of particles and $\mathrm{C}$ is the mass concentration of dust.

And usefulness of this equation was examined experimentally.

It was found that values of $p$ were proportional to product of density and mean diameter of particles. Regarding values of $\theta$, almost the same values were obtained for all samples tested regardless the difference in particle size and colour or dusts.

Calculated values of $\mathbf{K} \sigma$ obtained for various dusts vary with colour of dust.

From these experiments, it was proved that the equation was sufficiently useful to express the relation between the dust concentration and the response of the Digital Dust Indicator.

The practical method to evaluate the dust concentration in air by the Digital Dust Indicator was discussed.

For the measurement of intensity of scattered light by dust particles, the integrating circuit of photoelectric current of photomultiplier had been developed by the author.1) This circuit is capable of transforming electric current into digital amount. Applying this circuit, three kinds of dust indicator; Model-P for the portable device, Model-S for the use of multiple purposes and Model-A for the estimation of particulate matter in air pollutants, were devised. And these instruments were named the Digital Dust Indicator.

In this report, effects of size, density and relative scattering coefficient of particles to the value of dust concentration estimated by the Digital Dust Indicator will be discussed based on the results of several experiments.

The dust concentration $\mathrm{C}$ appeared in this report, was defined as the mass concentration expressed in $\mathrm{mg} / \mathrm{m}^{3}$ from following several reasons. 


\section{S. KOSHI}

The absolute concentration of dust in the air is expressed usually by either mass concentration or particle number concentration.

Some inevitable errors in the estimation of particle number concentration had been analysed by the author. ${ }^{2,3)}$ And, explanation was also given, why accurate estimation of dust concentration could not be expected by this method. If the sampling air volume could be estimated accurately enough, the more stable estimation of dust concentration may be obtained in mass concentration than in particle number concentration.

\section{APPARATUS}

The section of detector used in this experiment is shown in Fig. 1, which is the same to that used in Model-S and Model-A.

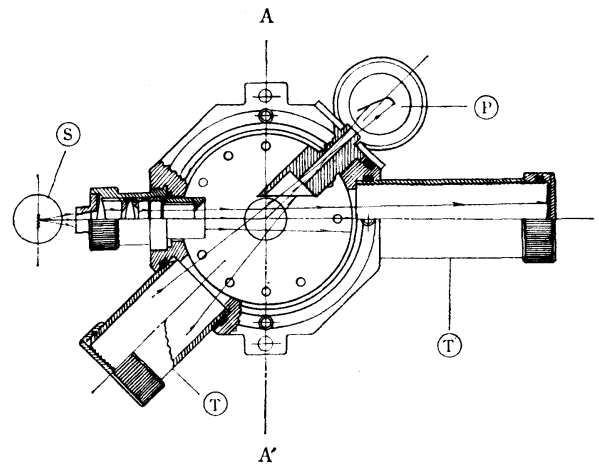

Fig. 1 a)
Fig. 1 b)

Fig. 1 c)
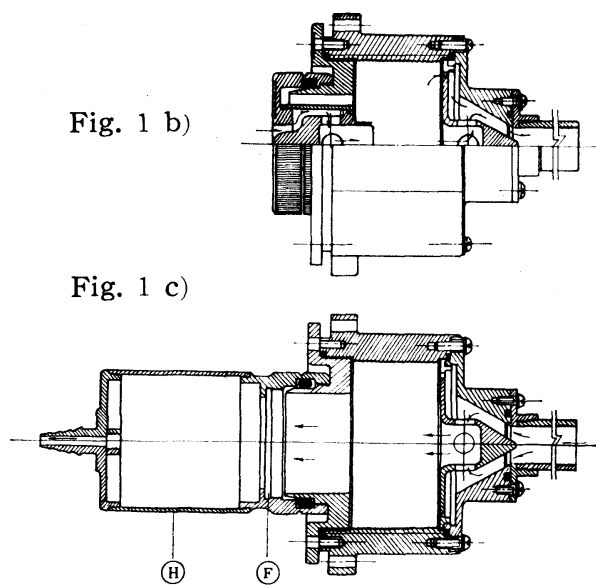

Fig. 1. Section of the detectorpart of Digital Dust Indicator.

In this figure, $\mathrm{S}$ is light source, $\mathrm{T}$ are light traps to avoid the effect of reflected light from inside wall of the detector.

The aspirated air passes through the detector vertically to the plane of the Fig. 1 a) and parallel to the Fig. 1 b) or 1 c).

The light scattered by dust particles at angle of $135^{\circ}$ against incident beam, is received on the cathode of photomultiplier $\mathrm{P}$ through the hole of $3 \mathrm{~mm}$ in diameter and $30 \mathrm{~mm}$ in length.

Fig. $1 \mathrm{~b}$ ) and c) are section of $\mathrm{A}-\mathrm{A}^{\prime}$ in Fig. 1 a).

$\mathrm{H}$ and $\mathrm{F}$ in Fig. $1 \mathrm{c}$ ) are the filter holder and the filter respectively.

In usual use of this detector in the determination of dust concentration, the air is aspirated in the direction shown with arrows in Fig. 1 b). For reading out the response of electrical device and for collection of dust particles at the same time, the apparatus in Fig. 1 c) was used which consisted of a detector and a glass fiber filter in holder. In this case, the direction of sampling air is reversed to that 


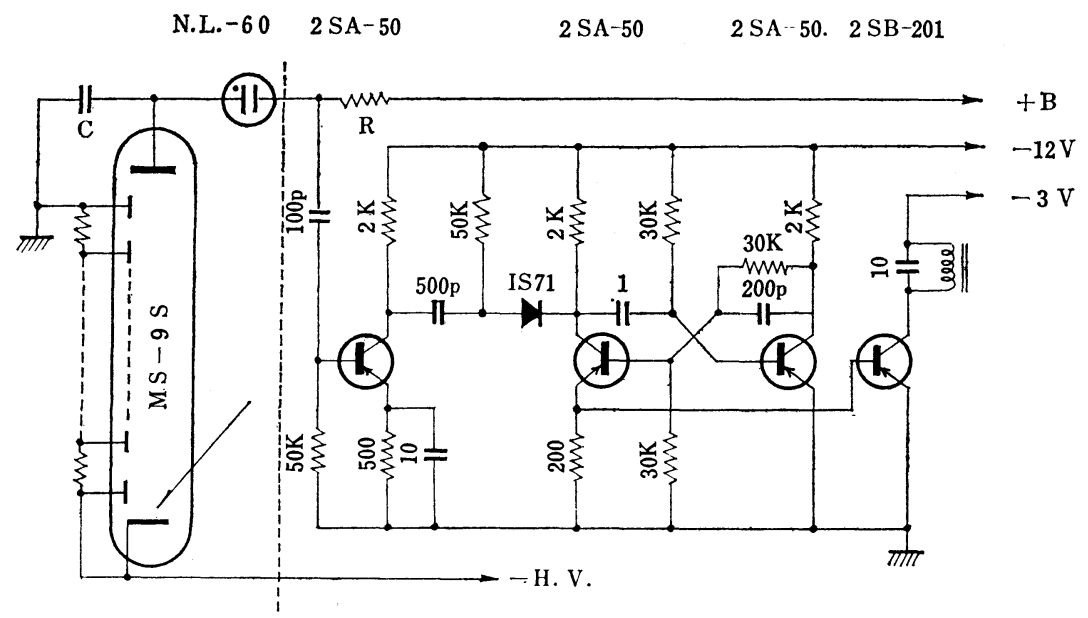

Fig. 2. The improved electric circuit of Digital Dust Indicator. The left side from dotted line is integrating circuit in which the photoelectric current is transformed into digital amount.

of in Fig. 1 b).

The electric circuit in Fig. 2, which is devised for measurment of light intensity scattered by dust particles, is principally identical to that reported in previous paper. Circuit constants chosen in this experiment were $2000 \mathrm{pF}$ for $\mathrm{C}, 50 \mathrm{~K} \Omega$ for $\mathrm{R}$ and $1 \mathrm{M} \Omega$ for loading resistors of photomultiplier. $-\mathrm{H} . \mathrm{V}$. and $+\mathrm{B}$ were adjusted to $-620 \mathrm{~V}$ and to $+150 \mathrm{~V}$ respectively.

The linear relation between photoelectric current and intensity of light received, is held stable in photomultiplier MS-9S, under the condion, where the ratio of the anode current to the current of loading resistor remains about $1: 100$ or below. On the other hand, the difference of starting and preservation potential of N.L.-60 is about $15 \mathrm{~V}$. Accordingly, this circuit is stable until the counting rate of 1500 c.p.m.

For the counting circuit of pulses induced in integrating circuit, the method of monostable multivibrator was used instead of thyratron, under consideration of stability of circuit. The output pulse from monostable multivibrator had about 40 msec. in width.

\section{RELATION BETWEen THE RESPONSE OF THE Digital DUST INDICATOR AND THE DUST CONCENTRATION}

At first, it was assumed that the photoelectric current of photomultiplier is linearly proportional to the light intensity received on its cathode.

As the number of pulses $R$ produced per unit time is proportional to photoelectric current, $R$ is proportional to the intensity $I$ of the light received on the cathode of photomultiplier. If the intensity of light illuminating the particle is $I_{0}$ the intensity of light $I_{S}$ by particles may be written $\left.{ }^{4}\right)$ 


\section{S. KOSHI}

$$
\mathrm{I}_{\mathrm{S}}=\mathrm{I}_{0} \mathrm{~A} \sigma \mathrm{Nd}^{2}
$$

where $\mathrm{A}$ is a constant, $\sigma$ is the relative scattering coefficient of dust particle, $\mathrm{N}$ is the number of particles per unit air volume and $d$ is the mean diameter of particle. Then, the mass concentration of dust $\mathrm{C}$ is given by

$$
\mathrm{C}=\mathrm{BN} \rho \mathrm{d}^{3}
$$

where $\rho$ and $\mathrm{B}$ are density and shape factor of particles respectively.

From equations (1) and (2)

$$
\mathrm{I}_{\mathrm{S}}=\mathrm{I}_{0} \mathrm{~A} \sigma \mathrm{C} / \mathrm{B} \rho \mathrm{d}
$$

In this equation, $\mathrm{I}_{\mathrm{S}}$ is expressed as a function of $\rho, \mathrm{C}, \sigma$ and $\mathrm{d}$.

For the estimation of dust concentration from observed value of $I_{S}$ or $R$, it is disadvantageous that the equation (3) includes $\rho$ and $d$, which are very troublesome to evaluate in usual way. Instead of $\rho$ and $d$, more easily observable quantity was found from the examination on the dissipation rate of dust particles in detector (see Experimentals 2 in detail). From the result of Experimentals 2, the dissipation of dust particles in detector is given by the equation

$$
\mathrm{C}_{\mathrm{t}}=\mathrm{C}_{0} \exp \cdot(-\mathrm{pt})
$$

where $C_{t}$ is initial dust concentration, $C_{0}$ is the dust concentration at the time $t$, and $\mathrm{p}$ is the dissipation coefficient. This is the equation for the rate of deposition of particles in turbulence in an enclosed vessel.

Experimentally, it was found that $\mathrm{p}$ is given by

$$
\mathrm{p}=\mathrm{D} \rho \mathrm{d}
$$

where $\mathrm{D}$ is a constant.

$$
\begin{aligned}
& \text { From equations (3) and (5) } \\
& \qquad I_{S}=I_{0} A \sigma C D / B p
\end{aligned}
$$

This equation is independent both of $\mathrm{d}$ and $\rho$.

If the dust concentration is very low and the absorption of light by particles is negligible, $I_{0}=I_{L}$ and $I_{S}=I$, where $I_{L}$ is the intensity of incident light to detector from lens system.

When dust concentrations are increased, and the absorption by particles can not be neglected, $\mathrm{I}_{0}$ and I should be written

$$
\left.\begin{array}{l}
I_{0}=I_{L} \exp \cdot\left(-1_{L} \varphi\right) \\
I=I_{S} \exp \cdot(-1 \subseteq \varphi)
\end{array}\right\}
$$

where $1_{\mathrm{L}}$ and $1_{\mathrm{S}}$ are the thicknesses of the aerosol layer traversed by the incident beam and the scattered light respectively.

If the extinction coefficient of particle is put $\mathrm{k}, \varphi$ is proportional to $\mathrm{kNd}^{2}$ from the Lambert-Beer law.

$$
\varphi=\mathrm{kNd}^{2}
$$

Eliminating $\mathrm{N}$ and $\mathrm{d}$ in the equation (8) by equations (2) and (5)

$$
\varphi=\mathrm{kDC} / \mathrm{Bp}
$$

Then the response $\mathrm{R}$, which is observed as the number of count per minute, 


\section{DIGITAL DUST INDICATOR}

is linearly proportional to the intensity of light received by photomultiplier.

If the relative sensitivity of transformation circuit it $S, R$ is given from equations (6), (7) and (9)

$$
\mathrm{R}=\mathrm{K} \sigma \frac{\mathrm{C}}{\mathrm{p}} \exp \cdot\left(-\theta \frac{\mathrm{C}}{\mathrm{p}}\right)
$$

where

$$
\begin{aligned}
& \mathrm{K}=\mathrm{SI}_{\mathrm{L}} \mathrm{AD} / \mathrm{B} \\
& \theta=-\left(1_{\mathrm{L}}+1_{\mathrm{S}}\right) \mathrm{kD} / \mathrm{B}
\end{aligned}
$$

Values of $\mathrm{K}$ and $\theta$ are constants determined by the condition of device, if minor variations of $\mathrm{k}$ among various dust is negligible.

\section{DUST MATERIALS}

\begin{tabular}{|c|c|c|c|c|c|c|}
\hline \multicolumn{2}{|c|}{$\begin{array}{l}\text { Sample } \\
\text { number }\end{array}$} & \multirow{2}{*}{$\frac{\text { Density }}{2.8}$} & \multirow{2}{*}{$\begin{array}{c}\text { Mean } \\
\underset{(\mu)}{\text { diameter }} \\
-\end{array}$} & \multirow{2}{*}{$\begin{array}{c}\begin{array}{c}\text { Standard } \\
\text { deviation } \\
(\mu)\end{array} \\
-\end{array}$} & \multirow{2}{*}{$\begin{array}{l}\text { Colour of dust } \\
\text { white }\end{array}$} & \multirow[t]{2}{*}{ Note } \\
\hline 1 & Calcium carbonate & & & & & \\
\hline 2 & Quartz & 2.6 & - & - & $"$ & \\
\hline 3 & Kantō loam & 3.0 & - & - & brown & \\
\hline 4 & Green tuff & 2.3 & - & - & greenish gray & \\
\hline 5 & Lead & 11.3 & 1.12 & 0.27 & black & \\
\hline 6 & Horn blend & - & - & - & dark green & \\
\hline 7 & Clay slate & - & - & - & gray & \\
\hline 8 & Biotite & - & - & - & brownish gray & \\
\hline 9 & Magnesium oxide & 3.6 & - & - & white & \\
\hline 10 & Coal & 1.4 & - & - & black & Bibai \\
\hline & Carbon black & 1.8 & 0.27 & 0.07 & " & Miike no. 20 \\
\hline 12 & " & " & 0.13 & - & " & Asahi no. 50 \\
\hline 13 & " & " & 0.05 & - & " & Tōkai no. 116 \\
\hline 14 & " & $"$ & 0.20 & 0.08 & " & Shiraishi \\
\hline 15 & " & $"$ & 0.03 & - & " & Tōkai HAF \\
\hline 16 & " & " & 0.03 & - & " & Spheron C \\
\hline 17 & " & " & 0.04 & - & " & Phil O \\
\hline 18 & " & " & 0.03 & - & " & Mitsubishi no. 100 \\
\hline 19 & " & " & 0.06 & - & " & Pearless II A \\
\hline 20 & $"$ & " & 0.02 & - & " & Nippil S \\
\hline 21 & Fly ash & 2.4 & 2.67 & - & gray & \\
\hline 22 & Polyvinyl chloride & 1.4 & 0.96 & 0.06 & white & Nihon carbide \\
\hline 23 & " & $"$ & 0.65 & 0.03 & " & Sumitomo \\
\hline 24 & " & " & 0.52 & 0.03 & " & Nihon carbide \\
\hline 25 & " & " & 0.44 & 0.04 & " & $"$ \\
\hline 26 & " & " & 0.42 & 0.03 & " & " \\
\hline 27 & " & " & 0.22 & 0.02 & " & " \\
\hline 28 & " & " & 0.12 & 0.01 & " & " \\
\hline
\end{tabular}

As shown in Table 1, various dusts were used to investigate the characteristics Table 1. Materials used in experiments. 


\section{S. KOSHI}

of the apparatus. Samples of number 2, 4, 6-8 and 10 in Table 1 were prepared by grinding. Lead fume (no. 5) was obtained from metal fume generator of the type of high frequency heating.5) The sample of number 21 was fly ash from electric power plant and uniformly sized by the method of water elutriation. All samples from number 11 to 20 were various carbon blacks of very uniform size. Kanto loam (volcanic ash) (no. 3) is the same to that provided in JIS (Japanese Industrial Standard) Z-8901 Class 8. The sample number 1 is calcium carbonate provided in Japan Pharmacopeia.

Magnesium oxide aerosol was obtained by burning of metalic magnesium.

Figs. 3-1) to 3-28) are electron micrographs of the above mentioned test aerosols. Samples for electron microscopy were prepared using the Jet Dust Counter after clouding into dust chamber.

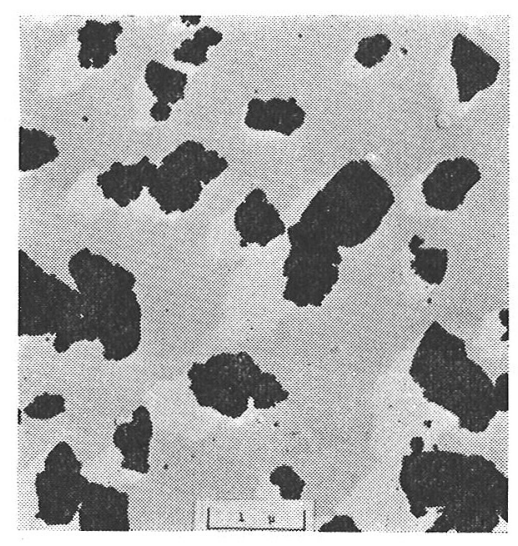

Fig. 3-1)

Calcium carbonate

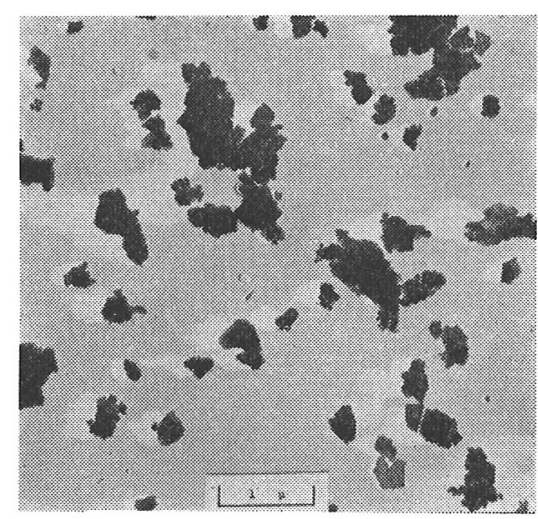

Fig. 3-3)

Kantō loam

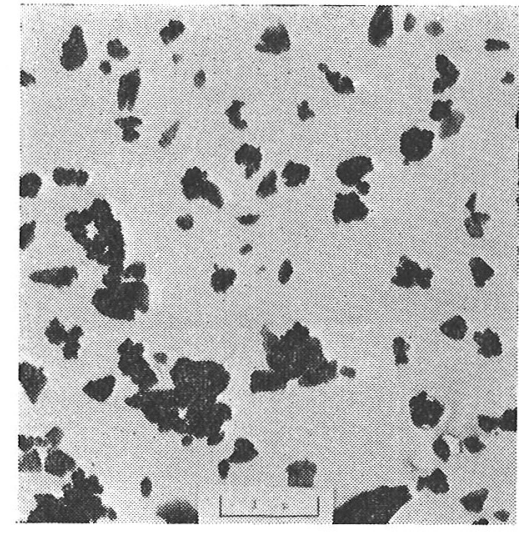

Fig. 3-2) Quartz

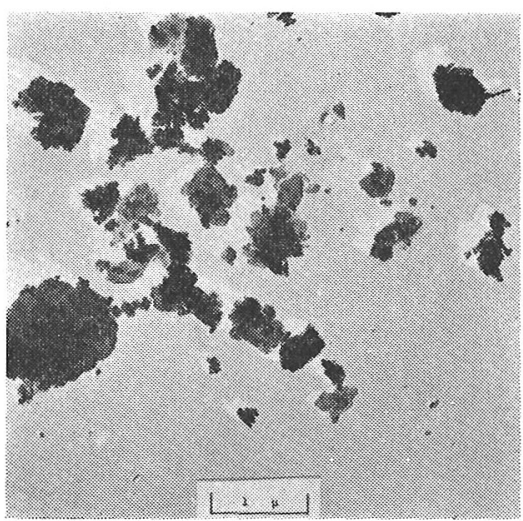

Fig. 3-4) Green tuff 
DIGITAL DUST INDICATOR

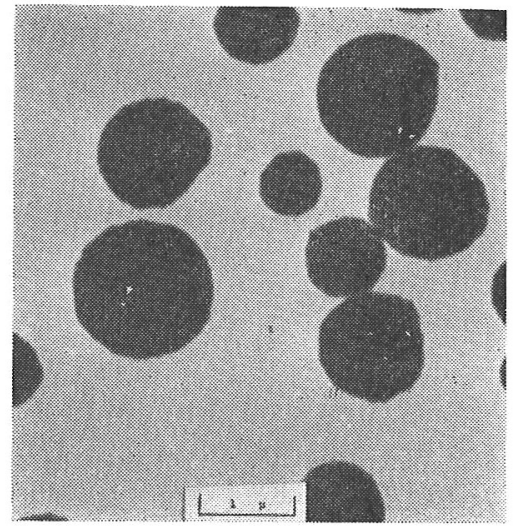

Fig. 3-5) Lead fume

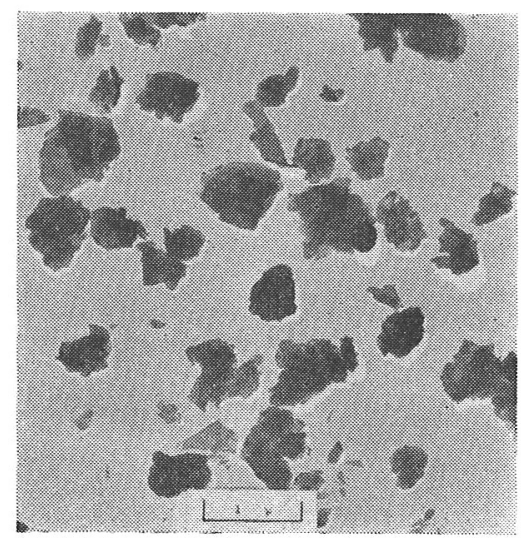

Fig. 3-7) Clay slate

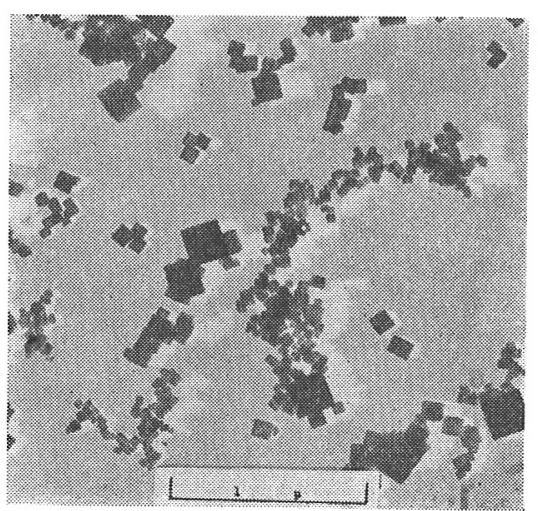

Fig. 3-9)

Magnesium oxide

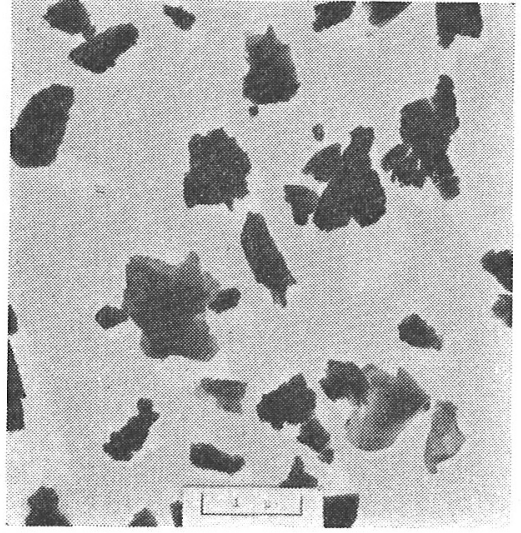

Fig. 3-6) Horn blend

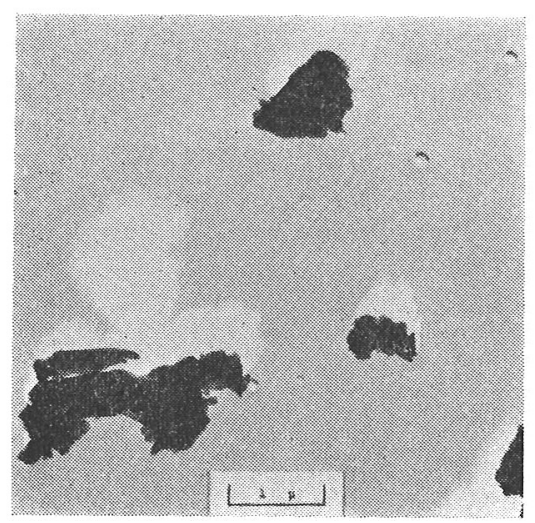

Fig. 3-8) Biotite

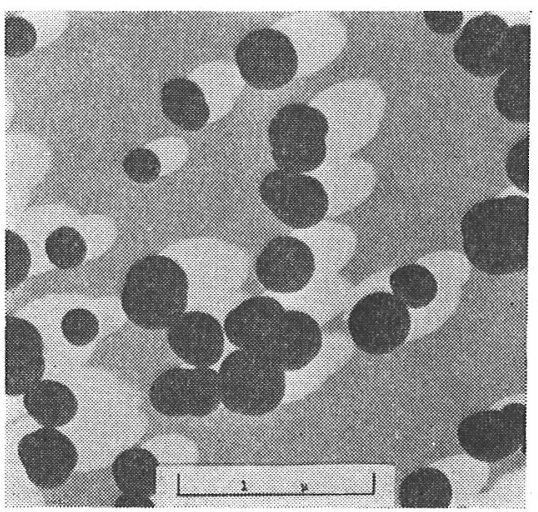

Fig. 3-11)

Carbon black Miike no. 20 


\section{S. KOSHI}

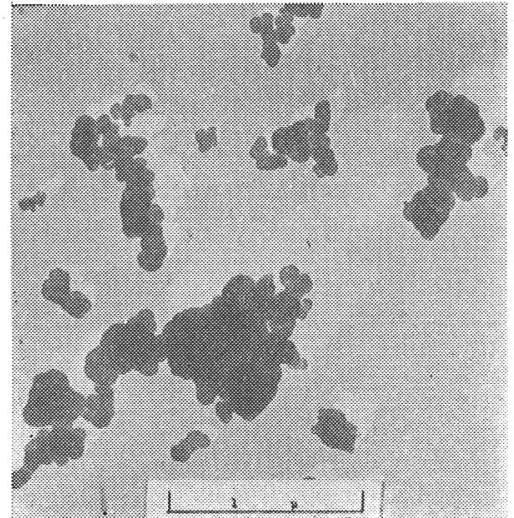

Fig. 3-12) carbon black Asahi no. 50

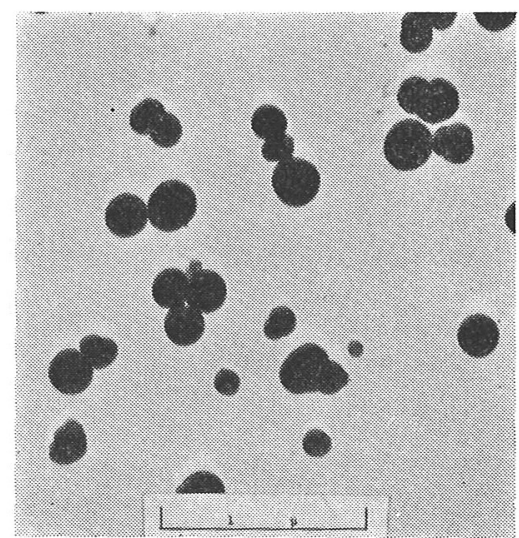

Fig. 3-14)

Carbon black Shiraishi

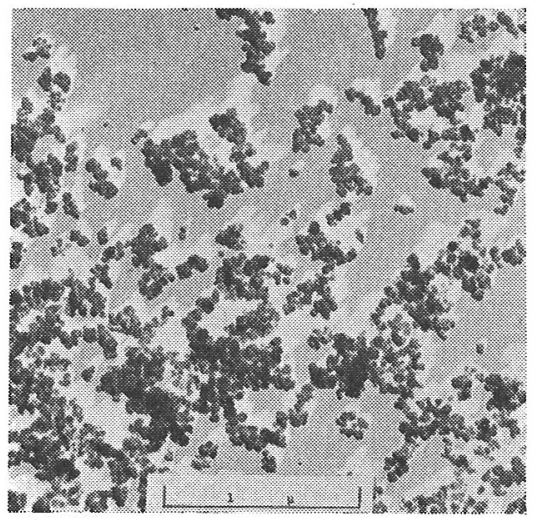

Fig. 3-16)

Carbon black Spheron C

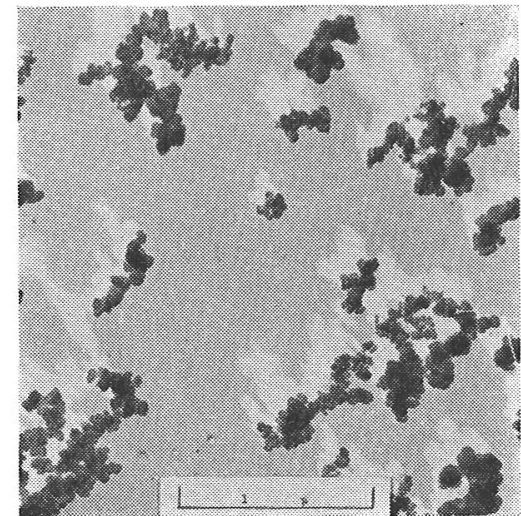

Fig. 3-13)

Carbon black Tōkai 116

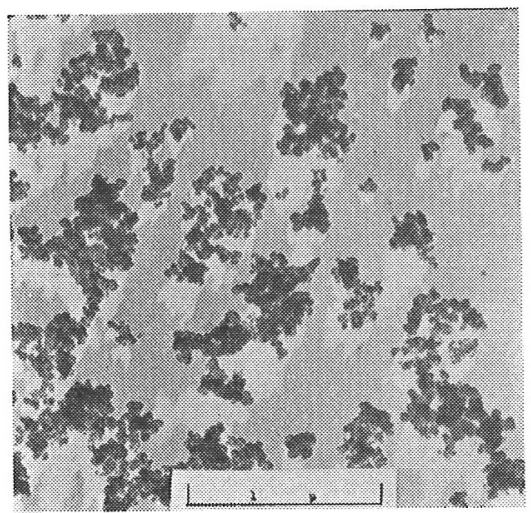

Fig. 3-15)

Carbon black Tōkai HAF

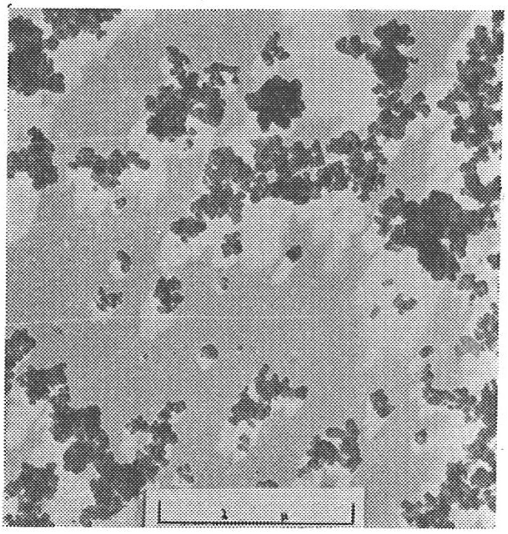

Fig. 3-17)

Carbon black Phil $\mathrm{O}$ 
DIGITAL DUST INDICATOR

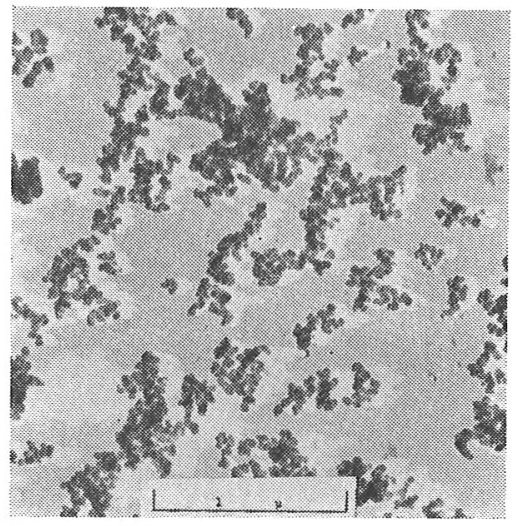

Fig. 3-18)

Carbon black Mitsubishi no. 100

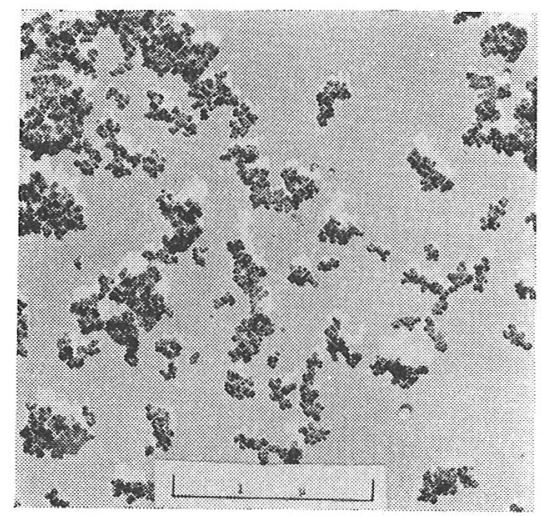

Fig. 3-20)

Carbon black Nippil S

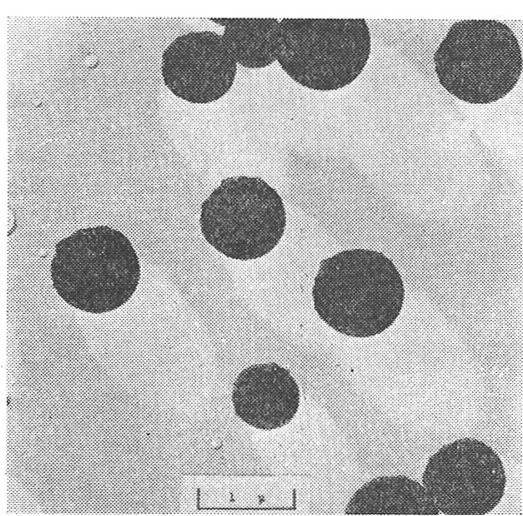

Fig. 3-22)

Polyvinyl chrolide

(P.V.C.) $0.96 \mu$

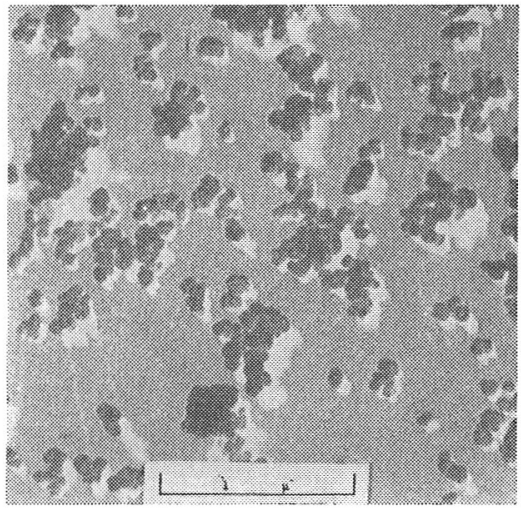

Fig. 3-19)

Carbon black Pearless II A

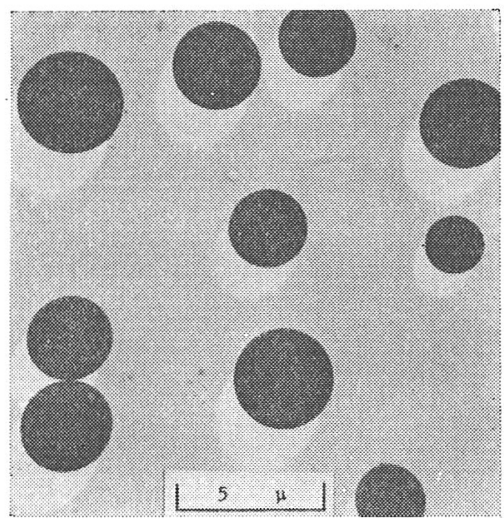

Fig. 3-21)

Fly ash

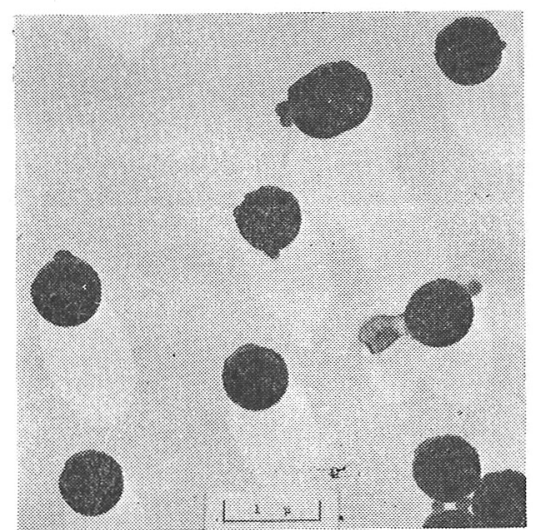

Fig. 3-23)

(P.V.C.) $0.65 \mu$ 


\section{S. KOSHI}

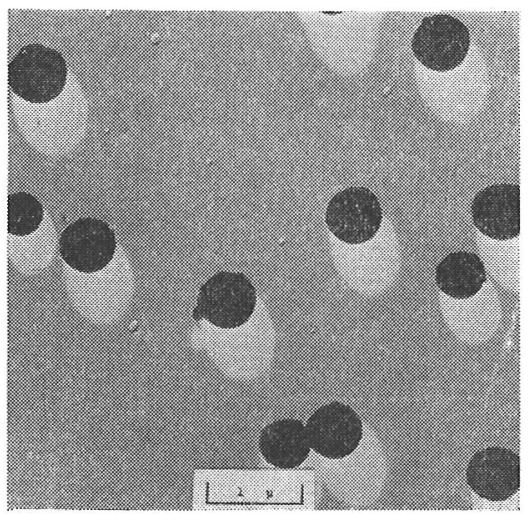

Fig. 3-24)

(P.V.C.) $0.52 \mu$

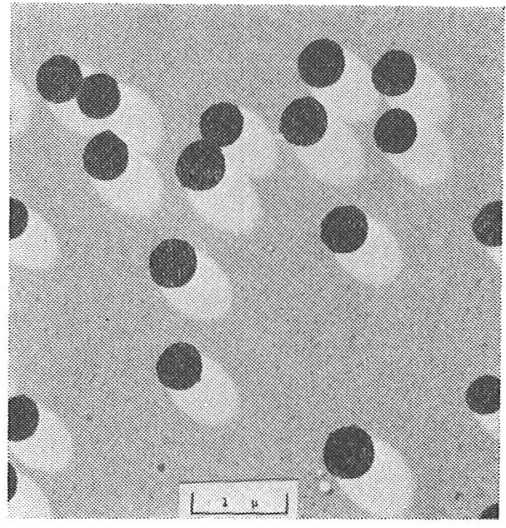

Fig. 3-26)

(P.V.C.) $0.42 \mu$

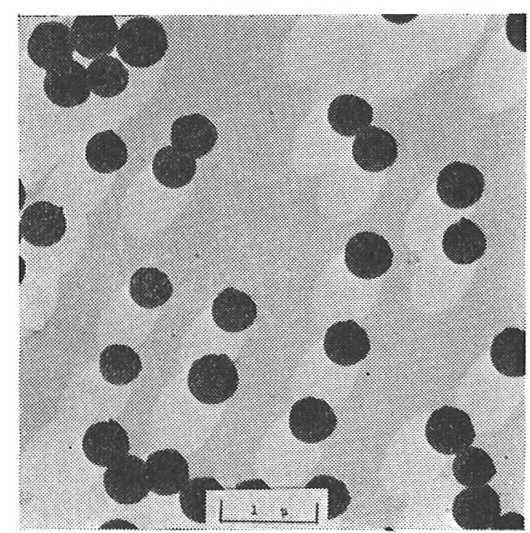

Fig. 3-25)

(P.V.C.) $0.44 \mu$

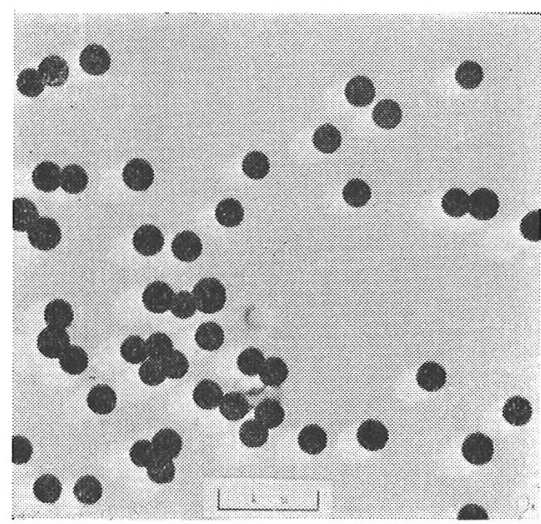

Fig. 3-27)

(P.V.C.) $0.22 \mu$

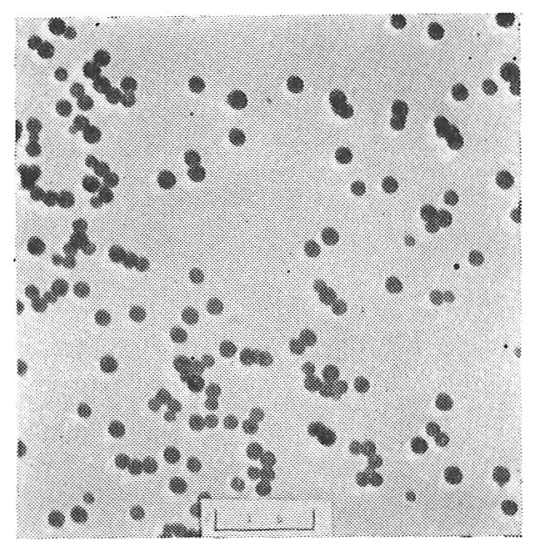

Fig. 3-28) (P.V.C.) $0.12 \mu$

Fig. 3. Electron micrographs of test dusts. 


\section{DIGITAL DUST INDICATOR}

\section{EXPERIMENTAS 1}

For the investigation of the relation between the dust concentration and the response of apparatus, the device shown in Fig. 1c) was used.

It is consisted of a detector and a glass fiber fiter set in the holder. The aspirated air pass through the detector and also the filter for a given time.

Responses of apparatus (number of count) were observed and amounts of dust collected on the filter were weighed.

Glass fiber filter with the collecting efficiency of $99.8 \%$ for $0.3 \mu$ particle was used, and initial weight of filter was about $0.1 \mathrm{~g}$ per $20 \mathrm{~cm}^{2}$. Sampling air velocity was 30 liter per minute and sampling time was from 10 to 15 minuites. As test aerosol, quartz (no. 2), calcium carbonate (no. 1) and carbon black (no. 16) were chosen.

Dust concentrations were obtained from the differences of weights of filters before and after sampling. To avoid the moisture, filter papers were dried in vacuum before weighing.

Results of experiments were plotted as seen in Fig. 4.

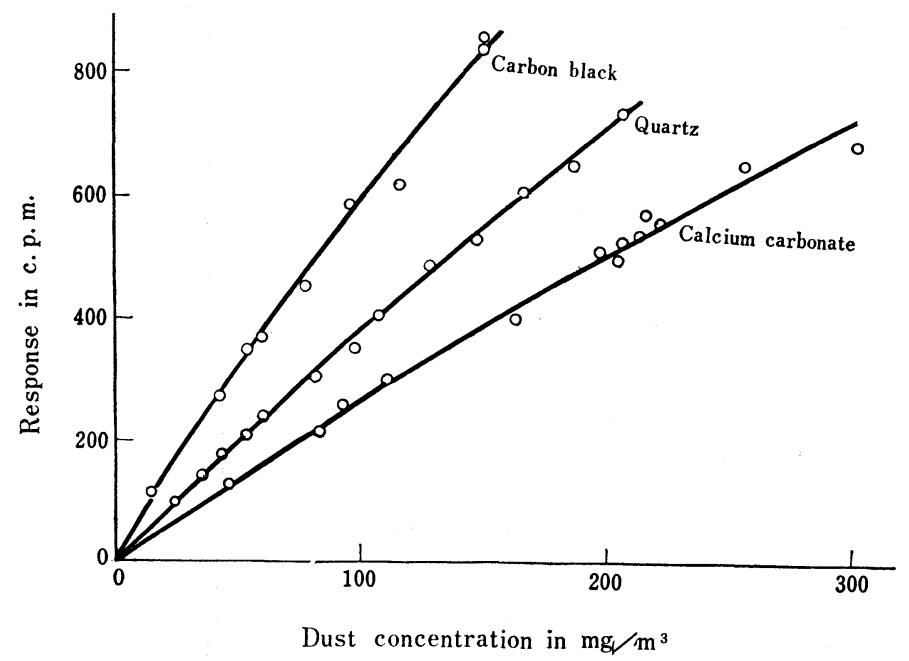

Fig. 4. The relation between the dust concentration and response of the Digital Dust indicator.

Responses of the apparatus are nearly proportional to dust concentrations, but the relation is not shown in a straight line. It may be explained by the absorption term in the equation (10) that the relation between the response and the dust concentration shows a slight curved line instead of straight one.

In above experiments, as values of $\mathrm{K}, \sigma, \mathrm{p}$ and $\theta$ are constants for each dust, variable in right side term of the equation (10) is the concentration $C$ only.

Hence, using the next equation, which is logarithmic expression of the equation (10), 


\section{S. KOSHI}

$$
l_{n}\left(\mathrm{R} \frac{\mathrm{C}}{\mathrm{p}}\right)=l_{n}(\mathrm{~K} \sigma)-\theta \frac{\mathrm{C}}{\mathrm{p}}
$$

values of $\theta$ for quartz, calcium carbonate and carbon black were calculated, and $6.6 \times 10^{-5}, 6.2 \times 10^{-5}$ and $5.8 \times 10^{-5}$ were obtained respectively.

Theoretically, the extinction coefficient should be a function of particle size parameter $\alpha=\pi \mathrm{d} / \lambda$ On the other hand, it was reported by Hodokinson6) that the mean particle total-extinction coefficient for a poly disperse assembly of randomlyoriented, transparent irregular particles, rose monotonically from zero to a constant 2 with increasing mean particle size. However, in this experiment, values of $\theta$ did not change significantly for variation in relative diameter $\mathrm{p} / \rho$ (see equation (5)).

This discrepancy may be explained by following reasons. Due to widely dispersed size distribution and coagulation of particles in the test aerosols in this experiments, the effective particle size distribution of dusts should be very complicated.

Furthermore, the incident light in this experiments was not monochrom, though Hodokinson used monochromatic light.

\section{EXPERIMENTALS 2}

The equation (3), which expresses the relation between the response of apparatus and the dust concentration, includes $\mathrm{d}$ and $\rho$. Measurments of these $\mathrm{d}$ and $\rho$ of aerosol particle are troublesome. It is desirable to eliminate $\mathrm{d}$ and $\rho$ in the equation (3) by any other more easily measurable parameter.

As a trial, let us consider the settling of dust particles in a small closed vessel. The simplest case is the settling of a monodisperse aerosol in stable air. Under this condition all particles fall at the same speed forming a cloud with a flat top. On the other hand, when the aerosol is stirred by convective type current, the number of particles per unit volume $\mathrm{N}_{\mathrm{t}}$ in an closed vessel at time $t$ is now given by the next equation in the first approximation 7 )

$$
\mathrm{N}_{\mathrm{t}}=\mathrm{N}_{0} \exp \cdot(-\mathrm{vt} / \mathrm{h})
$$

where $\mathrm{N}_{0}$ is the initial dust concentration in the vessel, $\mathrm{v}$ is the terminal velocity of the particle, and $\mathrm{h}$ is the height of the vessel.

The dust concentration in the vessel decreases exponentially with time.

The problem becomes more complicated when the aerosol is heterogeneous.

The case of stirred settling of a poly disperse aerosol had been considered by Sinclair.8) He assumed that the size distribution of the particles followed the log probability law, and that initially at zero time, the mass concentration $\mathrm{C}_{0}$ of aerosol was given by

$$
\mathrm{C}_{0}=\frac{\pi}{6} \mathrm{~N} \rho \mathrm{d}_{3}^{3}
$$




\section{DIGITAL DUST INDICATOR}

where $d_{3}$ is the volume diameter of particles. Then, he calculated, when $t$ is small in comparison to the value of $\mathrm{v} / \mathrm{h}$, the rate of dissipation of the mass concentration $\mathrm{C}_{\mathrm{t}}$ at time $\mathrm{t}$ and derived the following equation

$$
\cdots \mathrm{d}\left(\log \mathrm{C}_{\mathrm{t}}\right) / \mathrm{dt}=1.3 \times 10^{5} \rho \mathrm{d}_{8}^{2} / \mathrm{h} .
$$

In this equation, $d_{m}^{p}$ is generally defined by

$$
\log \mathrm{d}_{\mathrm{m}}^{\mathrm{p}}=\mathrm{p} \log \mathrm{d}_{\mathrm{g}}+2.303 \frac{\mathrm{pm}}{2} \log \sigma_{\sigma^{\prime}}
$$

where $\mathrm{d}_{\mathrm{g}}$ is the geometric mean diameter and $\sigma_{\mathrm{g}}$ is the geometric standard deviation.

However, it could not be always expected in all kinds of dusts that the size distribution of particles followed the log probability law. And, in this experiment, the slip factor on the terminal velocity of particles is not negligible, as the test dusts contain very small particles.

Then, if we put the equation (11) to the form of

$$
-\mathrm{d}\left(\log \mathrm{C}_{\mathrm{t}}\right) / \mathrm{dt}=\mathrm{p}
$$

$p$ is naturally the function of $\rho$ and $d$. By integrating the equation (12), we obtain for the small value of $t$

$$
\mathrm{C}_{\mathrm{t}}=\mathrm{C}_{0} \exp \cdot(-\mathrm{pt})
$$

which is the same to the equation (4).

Bearing above consideration in mind, the relation between $\mathrm{p}$ and $\mathrm{d}$ was examined using the detector instead of sedimentation vessel.

As test aerosols, polyvinyl chloride (from no. 22 to no. 28), carbon black (no. 11 and no. 14), fiy ash (no. 21) and lead fume (no. 5) were used. These particles are all spherical having uniform size as shown in Fig 3.

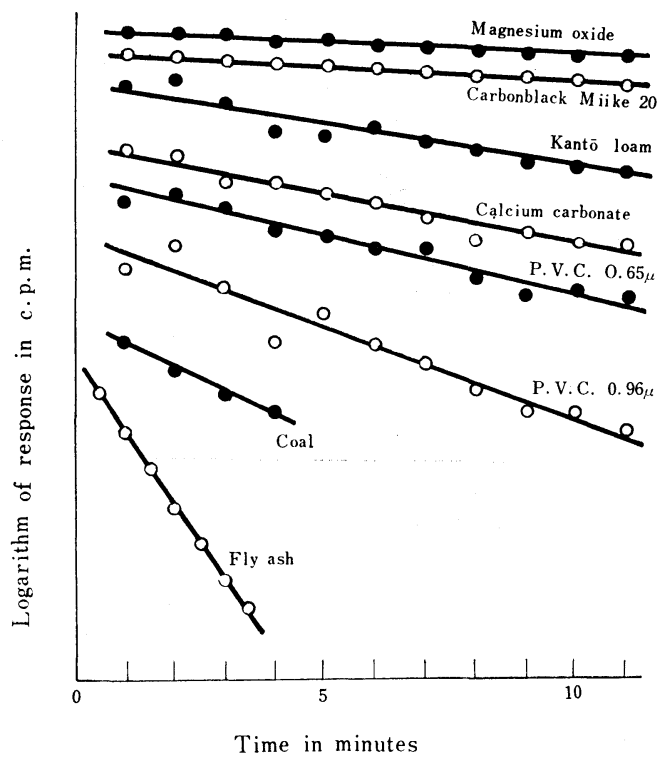

Fig. 5. The dissipation of dust particles in the detector with time. 


\section{S. KOSHI}

After the dust was introduced into the detector, the inlet and the outlet of the detector were shut. The dust concentration in detector decreased with time due to settling and diffusion, and observed response in every one minute decreased also with time.

Results of observations were shown in Fig. 5.

From the result of this examination, it is clear that the process of dissipation of dust in the detector fits to the equation (4).

Values of $\mathrm{p}$ are calculated by the finit differences method from observed values, that is, assuming $t$ is the time interval of observation

so

$$
\begin{aligned}
& \mathrm{C}_{\mathrm{t}}=\mathrm{C}_{0} \exp \cdot(-\mathrm{pt}) \\
& \mathrm{C}_{\mathrm{t}+\Delta \mathrm{t}}=\mathrm{C}_{\mathrm{t}} \exp \cdot(-\mathrm{p}(\mathrm{t}+\Delta \mathrm{t})) \\
& \mathrm{C}_{\mathrm{t}+\Delta \mathrm{t}}=\mathrm{C}_{\mathrm{t}} \exp \cdot(-\mathrm{p} \Delta \mathrm{t})
\end{aligned}
$$

Then the estimate of $\mathrm{p}$ is obtained from

$$
\exp \cdot(-\mathrm{p} \Delta \mathrm{t})=\Sigma \mathrm{C}_{\mathrm{t}+\Delta \mathrm{t}} \Sigma \mathrm{C}_{\mathrm{t}} / \Sigma \mathrm{C}_{\mathrm{t}}{ }^{2}
$$

by the least square method.

Values of calculated $\mathrm{p} / \rho$ were plotted against mean diameter of each particles as shown in Fig. 6. From this result, it is clear that $\mathrm{p}$ is proportional to $\rho \mathrm{d}$ and not $\rho$ d. ${ }^{2}$

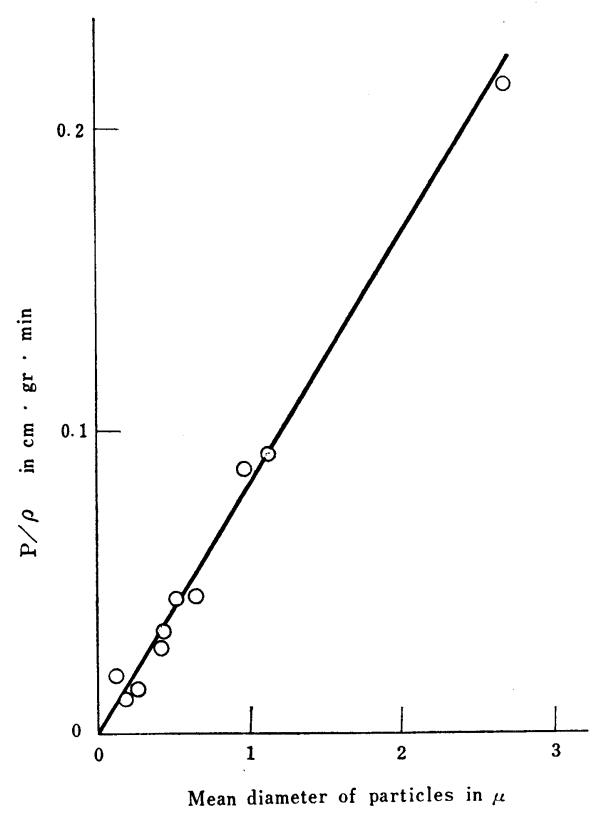

Fig. 6. The relation between the mean diameter of spherical particles and $\rho / \mathrm{p}$ where $\mathrm{p}$ is dissipation coefficient and $\rho$ is density of particle.

\section{EXPERIMENTALS 3}

The reliability of the equation (10) was tested by checking whether the calculated values of $\mathrm{K} \sigma$ in a dust could be uniform independently of the difference of 


\section{DIGITAL DUST INDICATOR}

its particle size.

For the calculation of $\mathrm{K} \sigma$ of each test dust, $\mathrm{n}$ (number of pulse produced in a given time), $\mathrm{C}$ and $\mathrm{p}$ were observed using the apparatus shown in Fig. $1 \mathrm{c}$ ) at the time 0,30, 60 and 120 minutes after dusting the test dust into dust chamber of about $30 \mathrm{~m}^{3}$ in capacity.

Observations of values $\mathrm{p}$ preceded by that of $\mathrm{n}$ using the same method as Experimentals 2. Observed values of $C, R$ and $p$, and calculated values of $R / C$, $\mathrm{K} \sigma$ and $\mathrm{K} \sigma / \mathrm{p}$ for various dusts are shown in Table 2.

Table 2. Observed values of $\mathrm{R}, \mathrm{C}$ and $\mathrm{p}$, and calculated values of $\mathrm{R} / \mathrm{C}, \mathrm{K} \sigma / \mathrm{p}$ and $\mathrm{K} \sigma$ for various dusts.

\begin{tabular}{|c|c|c|c|c|c|c|c|c|c|}
\hline $\begin{array}{l}\text { Sample } \\
\text { number }\end{array}$ & Dust & Time & $\mathrm{R}$ & $\mathrm{C}$ & $\mathrm{p}$ & $\mathrm{R} / \mathrm{C}$ & $\mathrm{K} \sigma / \mathrm{p}$ & $\mathrm{K} \sigma$ & $\begin{array}{l}\text { Mean value } \\
\text { of } \mathrm{K} \sigma\end{array}$ \\
\hline 1 & $\begin{array}{l}\text { Calcium } \\
\text { carbonate }\end{array}$ & $\begin{array}{r}0 \\
30 \\
60 \\
120 \\
\end{array}$ & $\begin{array}{l}769.8 \\
444.3 \\
321.4 \\
189.7 \\
\end{array}$ & $\begin{array}{r}231.23 \\
123.43 \\
72.27 \\
34.98 \\
\end{array}$ & $\begin{array}{l}0.102 \\
0.086 \\
0.086 \\
0.077 \\
\end{array}$ & $\begin{array}{l}3.33 \\
3.96 \\
4.44 \\
5.41 \\
\end{array}$ & $\begin{array}{l}3.82 \\
3.92 \\
4.68 \\
5.58\end{array}$ & $\begin{array}{l}0.39 \\
0.34 \\
0.40 \\
0.43 \\
\end{array}$ & 0.39 \\
\hline 2 & Quartz & $\begin{array}{r}0 \\
30 \\
30 \\
30 \\
60 \\
60 \\
120 \\
120\end{array}$ & $\begin{array}{l}487.3 \\
527.0 \\
340.1 \\
339.9 \\
254.0 \\
238.3 \\
170.0 \\
154.8\end{array}$ & $\begin{array}{r}139.40 \\
136.33 \\
77.03 \\
68.60 \\
55.13 \\
45.70 \\
31.38 \\
25.73\end{array}$ & $\begin{array}{l}0.081 \\
0.079 \\
0.084 \\
0.074 \\
0.070 \\
0.058 \\
0.072 \\
0.050\end{array}$ & $\begin{array}{l}3.50 \\
3.86 \\
4.41 \\
4.96 \\
4.60 \\
5.21 \\
5.41 \\
6.01\end{array}$ & $\begin{array}{l}3.82 \\
4.31 \\
4.65 \\
5.27 \\
4.86 \\
5.52 \\
5.55 \\
6.20\end{array}$ & $\begin{array}{l}0.31 \\
0.34 \\
0.39 \\
0.39 \\
0.34 \\
0.32 \\
0.40 \\
0.31\end{array}$ & 0.35 \\
\hline 3 & $\begin{array}{l}\text { Kantō loam } \\
\text { (volcanic ash) }\end{array}$ & $\begin{array}{r}0 \\
30 \\
60 \\
120 \\
\end{array}$ & $\begin{array}{r}331.2 \\
227.6 \\
153.9 \\
84.9 \\
\end{array}$ & $\begin{array}{l}98.43 \\
59.50 \\
33.36 \\
16.44 \\
\end{array}$ & $\begin{array}{l}0.074 \\
0.074 \\
0.076 \\
0.064 \\
\end{array}$ & $\begin{array}{l}3.36 \\
3.83 \\
4.61 \\
5.15 \\
\end{array}$ & $\begin{array}{l}3.65 \\
4.05 \\
4.74 \\
5.31 \\
\end{array}$ & $\begin{array}{l}0.27 \\
0.30 \\
0.36 \\
0.34 \\
\end{array}$ & 0.32 \\
\hline 4 & Green tuff & $\begin{array}{r}0 \\
30 \\
60 \\
120 \\
\end{array}$ & $\begin{array}{l}444.2 \\
306.0 \\
231.0 \\
156.8 \\
\end{array}$ & $\begin{array}{r}131.30 \\
67.50 \\
46.18 \\
26.00 \\
\end{array}$ & $\begin{array}{l}0.079 \\
0.065 \\
0.056 \\
0.053 \\
\end{array}$ & $\begin{array}{l}3.38 \\
4.53 \\
5.00 \\
6.04 \\
\end{array}$ & $\begin{array}{l}3.80 \\
4.78 \\
5.36 \\
6.23 \\
\end{array}$ & $\begin{array}{l}0.30 \\
0.31 \\
0.30 \\
0.33 \\
\end{array}$ & 0.31 \\
\hline 5 & Lead fume & - & 115.9 & 438.11 & 1.039 & 0.27 & 0.30 & 0.28 & 0.28 \\
\hline 6 & Horn blend & $\begin{array}{r}0 \\
30 \\
60 \\
120 \\
\end{array}$ & $\begin{array}{l}681.0 \\
502.1 \\
393.8 \\
265.9 \\
\end{array}$ & $\begin{array}{r}187.07 \\
121.60 \\
87.13 \\
53.00 \\
\end{array}$ & $\begin{array}{l}0.057 \\
0.060 \\
0.056 \\
0.055 \\
\end{array}$ & $\begin{array}{l}3.64 \\
4.14 \\
4.52 \\
5.02 \\
\end{array}$ & $\begin{array}{l}4.39 \\
4.68 \\
5.00 \\
5.46 \\
\end{array}$ & $\begin{array}{l}0.25 \\
0.28 \\
0.28 \\
0.30 \\
\end{array}$ & 0.28 \\
\hline 7 & Clay slate & $\begin{array}{r}0 \\
30 \\
60 \\
120 \\
\end{array}$ & $\begin{array}{r}257.1 \\
180.5 \\
137.2 \\
89.9 \\
\end{array}$ & $\begin{array}{l}77.40 \\
37.77 \\
27.47 \\
16.00 \\
\end{array}$ & $\begin{array}{l}0.060 \\
0.058 \\
0.053 \\
0.047\end{array}$ & $\begin{array}{l}3.56 \\
4.78 \\
5.00 \\
5.61 \\
\end{array}$ & $\begin{array}{l}3.84 \\
5.00 \\
5.10 \\
5.73 \\
\end{array}$ & $\begin{array}{l}0.23 \\
0.29 \\
0.27 \\
0.27 \\
\end{array}$ & 0.27 \\
\hline 8 & Biotite & $\begin{array}{r}0 \\
30 \\
60 \\
120 \\
\end{array}$ & $\begin{array}{l}655.3 \\
476.0 \\
380.3 \\
265.3 \\
\end{array}$ & $\begin{array}{r}152.90 \\
96.63 \\
70.90 \\
44.63 \\
\end{array}$ & $\begin{array}{l}0.054 \\
0.046 \\
0.050 \\
0.043 \\
\end{array}$ & $\begin{array}{l}4.28 \\
4.93 \\
5.38 \\
5.95 \\
\end{array}$ & $\begin{array}{l}5.00 \\
5.65 \\
5.80 \\
6.29 \\
\end{array}$ & $\begin{array}{l}0.27 \\
0.26 \\
0.29 \\
0.27 \\
\end{array}$ & 0.27 \\
\hline 9 & $\begin{array}{l}\text { Magnesium } \\
\text { oxide }\end{array}$ & $\begin{array}{r}0 \\
30 \\
60 \\
120\end{array}$ & $\begin{array}{l}369.8 \\
367.4 \\
298.7 \\
212.5 \\
\end{array}$ & $\begin{array}{l}40.50 \\
45.87 \\
36.69 \\
25.44 \\
\end{array}$ & $\begin{array}{l}0.018 \\
0.022 \\
0.021 \\
0.023 \\
\end{array}$ & $\begin{array}{l}9.13 \\
8.02 \\
8.14 \\
8.37\end{array}$ & $\begin{array}{r}10.57 \\
9.09 \\
9.05 \\
9.12 \\
\end{array}$ & $\begin{array}{l}0.19 \\
0.20 \\
0.19 \\
0.21 \\
\end{array}$ & 0.20 \\
\hline 10 & Coal & $\begin{array}{r}0 \\
30 \\
60 \\
120 \\
\end{array}$ & $\begin{array}{r}324.7 \\
181.2 \\
128.2 \\
75.3 \\
\end{array}$ & $\begin{array}{r}207.97 \\
91.23 \\
56.20 \\
26.00 \\
\end{array}$ & $\begin{array}{l}0.101 \\
0.086 \\
0.081 \\
0.065 \\
\end{array}$ & $\begin{array}{l}1.55 \\
1.98 \\
2.28 \\
2.89 \\
\end{array}$ & $\begin{array}{l}1.78 \\
2.10 \\
2.35 \\
2.93 \\
\end{array}$ & $\begin{array}{l}0.18 \\
0.18 \\
0.19 \\
0.19 \\
\end{array}$ & 0.19 \\
\hline 11 & $\begin{array}{l}\text { Carbon black } \\
\text { Miike no. } 20\end{array}$ & $\begin{array}{r}0 \\
30 \\
\end{array}$ & $\begin{array}{l}486.0 \\
317.1\end{array}$ & $\begin{array}{l}72.53 \\
51.80 \\
\end{array}$ & $\begin{array}{l}0.028 \\
0.024\end{array}$ & $\begin{array}{l}6.70 \\
6.14 \\
\end{array}$ & $\begin{array}{l}7.86 \\
7.09\end{array}$ & $\begin{array}{l}0.22 \\
0.17\end{array}$ & 0.19 \\
\hline 12 & $\begin{array}{l}\text { Carbon black } \\
\text { Asahi no. } 50\end{array}$ & $\begin{array}{r}0 \\
30 \\
60 \\
120 \\
\end{array}$ & $\begin{array}{l}557.0 \\
382.0 \\
294.3 \\
204.4 \\
\end{array}$ & $\begin{array}{r}132.37 \\
92.77 \\
72.63 \\
47.57 \\
\end{array}$ & $\begin{array}{l}0.026 \\
0.022 \\
0.024 \\
0.019 \\
\end{array}$ & $\begin{array}{l}4.21 \\
4.13 \\
4.05 \\
4.29 \\
\end{array}$ & $\begin{array}{l}5.78 \\
5.46 \\
5.00 \\
5.26 \\
\end{array}$ & $\begin{array}{l}0.15 \\
0.12 \\
0.12 \\
0.10 \\
\end{array}$ & 0.12 \\
\hline
\end{tabular}




\section{S. KOSHI}

Table 2. (continued)

\begin{tabular}{|c|c|c|c|c|c|c|c|c|c|}
\hline $\begin{array}{l}\text { Sample } \\
\text { number }\end{array}$ & Dust & Time & $\mathrm{R}$ & $\mathrm{C}$ & $\mathrm{p}$ & $\mathrm{R} / \mathrm{C}$ & $\mathrm{K} \sigma / \mathrm{p}$ & $\mathrm{K} \sigma$ & $\begin{array}{l}\text { Mean value } \\
\text { of } \mathrm{K} \sigma\end{array}$ \\
\hline 13 & $\begin{array}{l}\text { Carbon black } \\
\text { Tōkai no. } 116\end{array}$ & $\begin{array}{r}0 \\
30 \\
60 \\
120 \\
\end{array}$ & $\begin{array}{l}569.0 \\
420.3 \\
344.6 \\
233.7 \\
\end{array}$ & $\begin{array}{r}124.73 \\
78.60 \\
69.47 \\
46.57 \\
\end{array}$ & $\begin{array}{l}0.017 \\
0.018 \\
0.016 \\
0.015\end{array}$ & $\begin{array}{l}4.56 \\
5.36 \\
4.96 \\
5.01 \\
\end{array}$ & $\begin{array}{l}7.06 \\
7.22 \\
6.26 \\
6.00\end{array}$ & $\begin{array}{l}0.12 \\
0.13 \\
0.10 \\
0.09\end{array}$ & 0.11 \\
\hline 14 & $\begin{array}{l}\text { Carbon black } \\
\text { Shiraishi }\end{array}$ & $\begin{array}{r}0 \\
30 \\
60 \\
120 \\
\end{array}$ & $\begin{array}{l}334.7 \\
241.8 \\
192.2 \\
133.7 \\
\end{array}$ & $\begin{array}{l}75.27 \\
55.94 \\
45.10 \\
30.84 \\
\end{array}$ & $\begin{array}{l}0.022 \\
0.022 \\
0.022 \\
0.018\end{array}$ & $\begin{array}{l}4.43 \\
4.33 \\
4.27 \\
4.33 \\
\end{array}$ & $\begin{array}{l}5.46 \\
5.00 \\
5.00 \\
5.00\end{array}$ & $\begin{array}{l}0.12 \\
0.11 \\
0.11 \\
0.09\end{array}$ & 0.11 \\
\hline 15 & $\begin{array}{l}\text { Carbon black } \\
\text { Tökai HAF }\end{array}$ & $\begin{array}{r}0 \\
30 \\
60 \\
120 \\
\end{array}$ & $\begin{array}{l}323.4 \\
251.5 \\
198.4 \\
120.6\end{array}$ & $\begin{array}{r}130.77 \\
85.63 \\
52.87 \\
31.33 \\
\end{array}$ & $\begin{array}{l}0.023 \\
0.020 \\
0.020 \\
0.015\end{array}$ & $\begin{array}{l}2.47 \\
2.94 \\
3.76 \\
3.85 \\
\end{array}$ & $\begin{array}{l}3.48 \\
4.00 \\
4.50 \\
4.67 \\
\end{array}$ & $\begin{array}{l}0.08 \\
0.08 \\
0.09 \\
0.07\end{array}$ & 0.08 \\
\hline 16 & $\begin{array}{l}\text { Carbon black } \\
\text { Spheron C }\end{array}$ & $\begin{array}{r}0 \\
30 \\
60 \\
120 \\
\end{array}$ & $\begin{array}{r}209.1 \\
158.7 \\
123.6 \\
84.7 \\
\end{array}$ & $\begin{array}{r}129.83 \\
82.47 \\
59.23 \\
45.83 \\
\end{array}$ & $\begin{array}{l}0.033 \\
0.032 \\
0.029 \\
0.026\end{array}$ & $\begin{array}{l}1.61 \\
1.92 \\
2.08 \\
1.85 \\
\end{array}$ & $\begin{array}{l}2.12 \\
2.12 \\
2.41 \\
1.92 \\
\end{array}$ & $\begin{array}{l}0.07 \\
0.07 \\
0.07 \\
0.05\end{array}$ & 0.07 \\
\hline 17 & $\begin{array}{l}\text { Carbon black } \\
\text { Phil O }\end{array}$ & $\begin{array}{r}0 \\
30 \\
60 \\
120 \\
\end{array}$ & $\begin{array}{r}186.9 \\
139.7 \\
110.3 \\
79.1 \\
\end{array}$ & $\begin{array}{l}99.43 \\
61.17 \\
41.47 \\
23.90 \\
\end{array}$ & $\begin{array}{l}0.021 \\
0.022 \\
0.026 \\
0.018\end{array}$ & $\begin{array}{l}1.88 \\
2.28 \\
2.66 \\
3.31 \\
\end{array}$ & $\begin{array}{l}2.38 \\
2.73 \\
3.08 \\
3.88 \\
\end{array}$ & $\begin{array}{l}0.05 \\
0.06 \\
0.08 \\
0.07 \\
\end{array}$ & 0.06 \\
\hline 18 & $\begin{array}{l}\text { Carbon black } \\
\text { Mitsubishi } \\
\text { no. } 100\end{array}$ & $\begin{array}{r}30 \\
60 \\
120 \\
\end{array}$ & $\begin{array}{l}98.9 \\
78.9 \\
52.8 \\
\end{array}$ & $\begin{array}{l}48.70 \\
34.50 \\
19.03 \\
\end{array}$ & $\begin{array}{l}0.024 \\
0.024 \\
0.025\end{array}$ & $\begin{array}{l}2.03 \\
2.28 \\
2.77\end{array}$ & $\begin{array}{l}2.50 \\
2.50 \\
2.80 \\
\end{array}$ & $\begin{array}{l}0.06 \\
0.06 \\
0.07\end{array}$ & 0.06 \\
\hline 19 & $\begin{array}{l}\text { Carbon black } \\
\text { Pearless II A }\end{array}$ & $\begin{array}{r}0 \\
30 \\
60 \\
\end{array}$ & $\begin{array}{r}168.9 \\
128.0 \\
96.4 \\
\end{array}$ & $\begin{array}{r}108.60 \\
58.67 \\
34.40 \\
\end{array}$ & $\begin{array}{l}0.026 \\
0.018 \\
0.019 \\
\end{array}$ & $\begin{array}{l}1.76 \\
2.19 \\
2.81 \\
\end{array}$ & $\begin{array}{l}1.92 \\
2.78 \\
3.16 \\
\end{array}$ & $\begin{array}{l}0.05 \\
0.05 \\
0.06\end{array}$ & 0.05 \\
\hline 20 & $\begin{array}{l}\text { Carbon black } \\
\text { Nippil S }\end{array}$ & $\begin{array}{r}0 \\
30 \\
60 \\
120 \\
\end{array}$ & $\begin{array}{l}55.0 \\
41.1 \\
32.7 \\
21.4 \\
\end{array}$ & $\begin{array}{l}64.33 \\
37.97 \\
26.53 \\
14.13 \\
\end{array}$ & $\begin{array}{l}0.042 \\
0.027 \\
0.035 \\
0.027\end{array}$ & $\begin{array}{l}0.83 \\
1.08 \\
1.23 \\
1.52 \\
\end{array}$ & $\begin{array}{l}0.95 \\
1.11 \\
1.43 \\
1.48 \\
\end{array}$ & $\begin{array}{l}0.04 \\
0.03 \\
0.05 \\
0.04 \\
\end{array}$ & 0.04 \\
\hline
\end{tabular}

Values of $\mathrm{R} / \mathrm{C}$ increase clearly with time in almost every dusts except several kinds of dusts having very small and uniform size. These results could be explained by the decrease of concentration of dusts due to settling and also by the diminution of mean diameter of particles in the dust chamber. It is suggested that by decreasing of values of $p$ in each dust mean diameters of particles decrease with time.

Variations of values of $\mathrm{K} \sigma / \mathrm{p}$ are smaller than that of $\mathrm{R} / \mathrm{C}$, as the former are independent of the effects of the absorption of light by particles.

In order to show quantitatively that the effects of particle size and absorption of light by particles were minimized in calculated values of $\mathrm{K} \sigma$ by the equation (10), variations of $\mathrm{R} / \mathrm{C}, \mathrm{K} \sigma / \mathrm{p}$ and $\mathrm{K} \sigma$ were analysed by the two way rayout with factors of time, dust and error. Unbiased variances $\mathrm{u}_{\mathrm{t}}^{2}, \mathrm{u}_{\mathrm{B}}^{2}$ and $\mathrm{u}_{\mathrm{E}}^{2}$ in Table 3 were obtained from analysis of variance table, and $\mathrm{u}_{\mathrm{t}}^{2}$ is the unbiased variance caused

Table 3. Unbiased variances calculated from analysis of variance table.

\begin{tabular}{r|l|l|l|r|r}
\hline Variable & \multicolumn{1}{|c|}{$\mathrm{u}_{\mathrm{E}}^{2}$} & \multicolumn{1}{|c|}{$\mathrm{u}_{\mathrm{t}}^{2}$} & \multicolumn{1}{|c|}{$\mathrm{u}_{\mathrm{B}}^{2}$} & $\mathrm{u}_{\mathrm{t}}^{2} / \mathrm{u}_{\mathrm{E}}^{2}$ & $\mathrm{u}_{\mathrm{B}}^{2} / \mathrm{u}_{\mathrm{E}}^{2}$ \\
\hline $\mathrm{R} / \mathrm{C}$ & 0.1826 & 0.2425 & 2.1350 & 1.328 & 11.69 \\
$\mathrm{~K} \sigma / \mathrm{p}$ & 0.4855 & 0.09833 & 3.3813 & 0.202 & 6.97 \\
$\mathrm{~K} \sigma$ & 0.000530 & 0.000001 & 0.013652 & 0.002 & 25.76 \\
\hline
\end{tabular}




\section{DIGITAL DUST INDICATOR}

by difference of observing time, $\mathrm{u}_{\mathrm{B}}^{2}$ is the unbiased variance caused by kinds of dust and $\mathrm{u}_{\mathrm{E}}^{2}$ is the unbiased variance of error.

Values of $\mathrm{R} / \mathrm{C}$ are influenced by particle size and light absorption, and $\mathrm{K} \sigma / \mathrm{p}$ only by particle size.

Then, as seen in Table $3, \mathrm{u}_{\mathrm{t}}^{2}$ for $\mathrm{R} / \mathrm{C}$ and $\mathrm{K} \sigma / \mathrm{p}$ are significantly larger than $\mathrm{u}_{\mathrm{E}}^{2}$. On the other hand, the value of $\mathrm{u}_{t}^{2} / \mathrm{u}_{\mathrm{E}}^{2}$ for $\mathrm{K} \sigma$ is very small in comparison with that of $\mathrm{R} / \mathrm{C}$ or $\mathrm{K} \sigma / \mathrm{p}$. These results show the usefulness of the equation (10) to express the relation between the dust concentration and the response of this device.

Theoretically, the value of $\mathrm{k} \sigma$ should depend upon the difference in optical characteristics of particle surface. In this experiment, the variation of mean values of $\mathrm{K} \sigma$ of test dusts seems to depend on the light reflectivity of dust particle. But, in the case of very fine and coagulative particles, small values of $\mathrm{K} \sigma$, which could not be expected from the above mentioned explanation on the value of $\mathrm{K} \sigma$, were rarely observed. As seen in magnesium oxide fume, the marked tendency toward coagulation of particles resulted in larger value of $p$ than that of expected from its original particle size.

Consequently, the calculated value of $\mathrm{K} \sigma$ becomes smaller than that of expected from the colour of dust.

\section{EXPERIMENTALS 4}

In order to examine the effect of air velocity in the detetcor on the response, the relation between response and dust concentration was examined by the same method used in Experimentals 1 with sampling air velocities from 12 liter per minute to 38 liter per minute.

As shown in Fig. 7, values of $\mathrm{R} / \mathrm{C}$ remained stable over all range of sampling

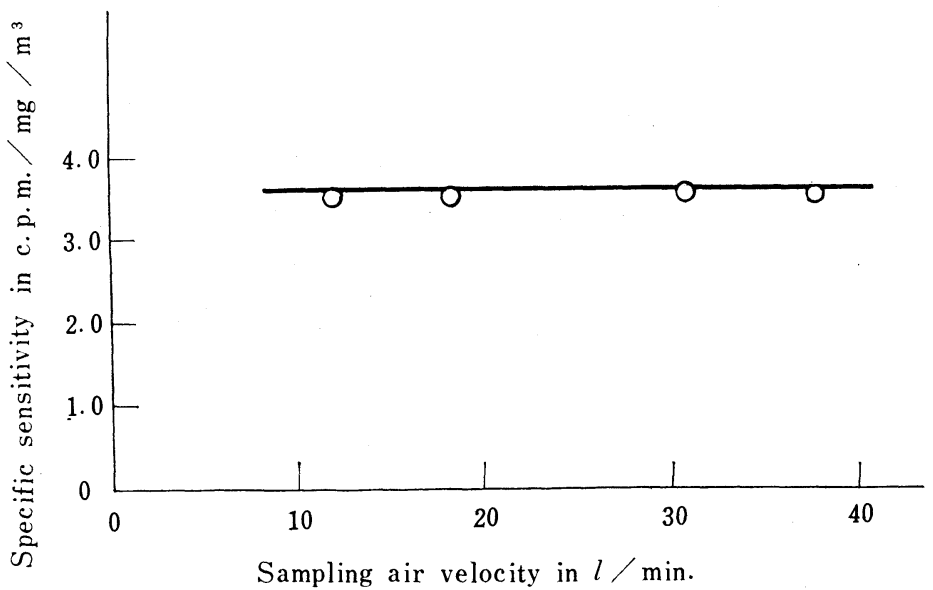

Fig. 7. The characteristic curve of flow velocity. 


\section{S. KOSHI}

velocities. This result shows that the response is unaffected by the velocity of particle in the detector. However, this result does not deny the possible effect of samplimg air velocity in practical dust determination, as the result obtained in this observation is limited solely on the relation between responses and dust concentrations in the detector and not in air outside the detector. That is, larger particles may be lost before detector due to settling when the sampling air velocity is very low, and also they may be lost in maze due to impaction for high sampling air velocity.

\section{Applications}

In this report, the equation, which expresses the relation between response of the Digital Dust Indicator and the dust concentration, was derived, and meaning of parameters was discussed based on the experimental results.

On the application of the Digital Dust Indicator, the most simplest case is the observation of relative concentration of aerosol in very low concentration. If the term of exp. $(-\theta \mathrm{C} / \mathrm{p})$ in the equation (10) is negligible, the observed response $\mathrm{R}$ shows relative dust concentration. Critical mass concentrations, in which calculated values of exp. $(-\theta \mathrm{C} / \mathrm{p})$ for various values of $\mathrm{p}$ remain 0.9 or 0.95 , were given in Table 4.

Table 4. Critical mass concentration for various values of $p$.

\begin{tabular}{c|c|c}
\hline exp. $(-\theta \mathrm{C} / \mathrm{p})$ & $\mathrm{p}$ & $\begin{array}{c}\text { Critical mass concentration } \\
\text { in } \mathrm{mg} / \mathrm{m}^{3}\end{array}$ \\
\hline \multirow{3}{*}{0.90} & 1.00 & 1750. \\
& 0.10 & 175. \\
& 0.05 & 87.5 \\
& 0.01 & 17.5 \\
\hline \multirow{3}{*}{0.95} & 1.00 & 850. \\
& 0.10 & 85. \\
& 0.05 & 42.5 \\
& 0.01 & 8.5 \\
\hline
\end{tabular}

When the mass concentration of dust is as high as the term exp. $(-\ell \mathrm{C} / \mathrm{p})$ could not be negligible, the method of estimation of relative dust concentration becomes more complicated because the equation (10) has not formal solution for $\mathrm{C}$. In this case, the process of estimation should correspond to that of mass concentration as discussed as follows.

The Digital Dust Indicator was originally devised to estimate the relative dust concentration and neither to determine the mass nor particle number concentration of dust. However, the estimation of mass concentration of dust is often very important in the field of industrial hygine. If the value of $\mathrm{K} \sigma$ for a dust in question is known, the mass concentration of this dust may be easily estimated using 


\section{DIGITAL DUST INDICATOR}

the Digital Dust Indicator.

The mass concentration of dust can be estimated by following procedure.

If the value of $\mathrm{K} \sigma$ for a dust is unknown, that value must be estimated in advance by the method used in Experimentals 3 .

(1) Observe the value of $\mathrm{R}$ and $\mathrm{p}$ using the apparatus.

(2) Calculate $\mathrm{R} / \mathrm{K} \sigma$ dividing $\mathrm{R}$ expressed in c.p.m. by $\mathrm{K} \sigma$.

(3) Find out the value of $\mathrm{C} / \mathrm{p}$ corresponding to the value of $\mathrm{R} / \mathrm{K} \sigma$ from Table 5 .

(4) Consequently, the mass concentration $\mathrm{C}$ is obtained multiplying the value of $\mathrm{C} / \mathrm{p}$ by the dissipation coefficient $\mathrm{p}$.

Table 5. Calculated values of $\mathrm{F}(\mathbf{x} \mid \theta)$.

\begin{tabular}{|c|c|c|c|c|c|}
\hline $\mathrm{T} / 10 \quad \mathrm{~T}$ & 0000 & 1000 & 2000 & 3000 & 4000 \\
\hline 000 & 1.000 & 1.066 & 1.148 & 1.253 & 1.399 \\
\hline 100 & .006 & .073 & . 157 & .265 & .417 \\
\hline 200 & .012 & .081 & .166 & .278 & .436 \\
\hline 300 & .019 & .089 & .176 & .291 & .456 \\
\hline 400 & .025 & .097 & .186 & .305 & .477 \\
\hline 500 & .031 & .105 & 197 & .319 & .499 \\
\hline 600 & .038 & .113 & .207 & .334 & .522 \\
\hline 700 & .045 & .121 & .218 & .349 & .547 \\
\hline 800 & .052 & 130 & .229 & .365 & .573 \\
\hline 900 & .059 & .139 & .241 & .382 & .601 \\
\hline
\end{tabular}

Table 5 quoted in above mentioned procedure was calculated as follows.

Putting the equation (10) into the form of

$$
\mathrm{T} F(\mathrm{x} \mid \theta)=z
$$

where $T=R / K, z=C / p$ and exp. $(-\theta z)=1 / F(x \mid \theta)$, and calculated values of $F(x \mid \theta)$ were tabulated in Table 5. In this calculation, 0.00006 was used as the value of $\theta$.

\section{REFERENCES}

1) Koshi, S. (1964). Ind. Health, 2, 55.

2) Koshi, S. (1952). J. Sci. Labour, $28,447$.

3) Koshi, S. (1954). J. Sci. Labour, 30, 778.

4) Tolman, R. C. (1919). J. Am. Chem. Soc., 41, 300.

5) Honma, K. may be published.

6) Hodokinson, J. R. (1963). I. C. E. S., 87.

7) Green, H. L. and Lane, W. R. (1957). Particulate Clouds: Dusts, Smokes and Mists p. 168. E. \& F. N. Spon Ltd., London.

8) Sinclair, D. (1950). Handbook on Aerosols, U.S. Atomic Energy Commission, Washington. 